\title{
Study on the Practical Teaching Mode of Digital Media in Colleges and Universities
}

\author{
Wenzhong Cai \\ Kunming University \\ Kunming, China
}

Baifan Zhao

Yunnan Provincial Institute of Health Education

Kunming, China

\author{
Yu Shi \\ Kunming City Center for Disease Control and Prevention \\ Kunming, China \\ Xinping Luo \\ Yunnan Provincial Institute of Health Education \\ Kunming, China
}

\begin{abstract}
The theme of "Public Benefit Animation of Cigarette Control" is assigned to the students admitted separately in two years, making them create the short films of promotional animation in groups and making a comparison of their short films of animation created by the students who have a knowledge training of cigarette control and those who have no such a training, to find the factors that impact the quality of health propaganda film creation and further make a improvement in the process of guiding students. The students who have professional knowledge training obtained a higher average point for their works and good "customer satisfaction". And in terms of creativity and unrestrained and vigorous style, the students who have no professional knowledge training for customers showed have a more free performance. However, this is relative, and in this paper, we will discuss the significance of customer training for digital media animation education. Professional knowledge on cigarette control is an essential factor in the production of health videos. Teachers should teach students the correct knowledge when they are guiding students. At the same time, creativity should be used to integrate topical knowledge into the pictures, and at the same time, it can also solve the separation of theory from practice in the modern art education of colleges.
\end{abstract}

Keywords-digital media; teaching model; public benefit propaganda; comparative study

\section{INTRODUCTION}

At present, the college students in China cannot use their theoretical knowledge and techniques for a certain period of time after graduation, lack of hands-on ability and in noncompliance with the requirements of customers fully. Society and enterprises need the talents with professional skills and project experience, so colleges and universities should do their best to cultivate the students with relevant skills to meet the needs of the society.

\section{Design of Digital Media Practical Education MODEL}

Let us understand the training objectives of digital media majors in some colleges and universities: to cultivate the advanced applied professional talents who much have professional knowledge and ability in systematic art design and creation and in teaching and research, master modern design theory, digital media, and new media technologies, understand and maser ethnic and folk traditional culture and art, have the ability to work in art design, digital media, teaching management, etc. in the organizations of art design, education research, production and management, meet the needs of the talent market, possess the core competence of digital media design and the related knowledge, have excellent ideological and moral qualities, solid theoretical basis, strong professional competence, high comprehensive quality, and strong application ability, and are developed in a moral, intellectual, and physical manner.

Here we can find that digital media is a newly developed industry, and compared with other industries, it needs more comprehensive learning and improvement. In the field of digital media, there is even a cross-border, so the cultivation of comprehensive quality is also a top priority.

At present, most of art design and digital media education in China's colleges belong to research or applied education. Many colleges and universities emphasize the applied education, and adopt an educational model that links theory with practice and that is associated with the society.

Students are generally taught in a small class or in a mentoring studio, and no matter which requires a relatively practical project for creation and practice.

Under such an education model, students have their creative practice generally in two types:

1. Teachers or students self plan a title of "really existing" project, and the organization exists as an individual, but it is not directly connected to the real Party A, and the assessment of works score is still dominated by the teacher.

2. Teachers or students directly do a real project, and the implementation of the project need a communication with Party $\mathrm{A}$, and the final results and performance evaluation depend on the social party $\mathrm{A}$ or is made by a joint judgment by social Party A and teachers. 
Which method is more suitable for the modern college education model, can better resolve the separation of modern art education theory from practice in colleges and preserve the advantages of college education?

\section{STUdy ON EFFECTIVE EdUCATION MOdEL BASED ON THE IMPLEMENTATION OF ACTUAL PROJECT}

\section{A. Program Design}

As an animation teacher at Kunming University, the author selected the students admitted respectively in two years to attempt the two educational models as aforementioned for the same subject in the class of "animation creation".

The objectives and objects: the students of 2011 digital media and that of 2013 digital media, who all do the course of the second semester of Grade 3 of college. They all have learned the foundation of such courses as graphic design, twodimensional animation, three-dimensional animation, movement law painting, network interaction, and film and television creation and can independently create related design works.

Creative theme: "Public Benefit Animation of Cigarette Control"

The way of creation: each grade is divided into 8 groups for creation, and each group is about 4 to 6 people, for a collective creation.

Type of creation: all are in category of animation, and should have artistic picture, smooth and rational and eyecatching originality.

Projects and assessment methods: the students of 2011 digital media used a virtual party A for their creation, and they did not have any training before production, they collected relevant information for themselves and did not communicate with customers. The project was not landed, and the final evaluation of score for results was conducted by the teacher according to the production process. The students of 2013 digital media used the real Party A that is the Tobacco Hazards and Control Office of the Yunnan Provincial Institute of Health Education, and they created the same public benefit animation of cigarette control. This is a real project and needs landing so they specially invited the Experts from the Office of Tobacco Hazards and Control Office of the Yunnan Provincial Institute of Health Education for a lecture and training on cigarette control before they started their creation, and then they are allowed to make a full communication with Party A, and the final evaluation was jointly assessed by the class teacher and Party A.

Each group has two months of study and creation. During the creation period, they are all directed by the same teacher. Their works are to be offered to the Yunnan Provincial Tobacco Control Office for use by excellent selection. After completed, the works are compared and assessed for their quality by their scores given by teachers and the customer satisfaction for them.

\section{B. Comparison of Works Evaluation Results}

The evaluation of the works includes two parts, the instructors' scoring and customers' satisfaction. First, the instructors' scoring, The instructor give score according to the score evaluation standard of routine assignments, in consideration of the overall effect, aesthetics of the pictures, the creativity of theme, animation fluency, etc., totaling 100 points. Second is the customers' satisfaction. The teachers of the Yunnan Provincial Institute of Health Education make an evaluation and give score mainly from the propaganda purpose and the expected publicity effect. (The comparison of score results is shown in Table I).

TABLE I. COMPARISON OF SCORES FOR THE CigARETTE CONTROL FILMS OF THE STUDENTS OF 2011 AND 2013

\begin{tabular}{|c|c|c|c|c|c|}
\hline \multirow{2}{*}{$\begin{array}{c}\text { Works of } \\
\text { Students } 2011\end{array}$} & \multicolumn{2}{|c|}{$\begin{array}{l}\text { Score from } \\
\text { Instructor }\end{array}$} & \multicolumn{2}{|c|}{$\begin{array}{l}\text { Customers' } \\
\text { Satisfaction }\end{array}$} & \multirow{2}{*}{$\begin{array}{c}\text { Works of } \\
\text { Students } \\
2013\end{array}$} \\
\hline & 2011 & 2013 & 2011 & 2013 & \\
\hline $\begin{array}{l}\text { No smoking, no } \\
\text { crying }\end{array}$ & 80 & 90 & 6 & 8 & LA LA LA \\
\hline Red and Black & 89 & 77 & 8 & 9 & $\begin{array}{l}\text { Benefits of } \\
\text { smoking }\end{array}$ \\
\hline No smoking & 77 & 60 & 4 & 7 & $\begin{array}{l}\text { Smoking is } \\
\text { suicide }\end{array}$ \\
\hline $\begin{array}{l}\text { Smoking can be } \\
\text { chosen by us, but } \\
\text { life? }\end{array}$ & 73 & 88 & 5 & 7 & $\begin{array}{l}\text { an } \\
\text { engagement } \\
\text { in a } \\
\text { propitious } \\
\text { time }\end{array}$ \\
\hline $\begin{array}{l}\text { Control smoking, } \\
\text { beauty the life }\end{array}$ & 95 & 80 & 8 & 7 & $\begin{array}{l}\text { Second hand } \\
\text { cigarettes and } \\
\text { haze }\end{array}$ \\
\hline $\begin{array}{l}\text { Cherish life, } \\
\text { refuses tobacco }\end{array}$ & 88 & 75 & 5 & 8 & $\begin{array}{l}\text { Harm of } \\
\text { smoking }\end{array}$ \\
\hline Cigarette is Hell & 75 & 95 & 5 & 9 & Xiaomi's Lab \\
\hline $\begin{array}{ll}\text { cigarettes } & \text { for } \\
\text { Social contact } & \end{array}$ & 60 & 85 & 4 & 6 & $\begin{array}{l}\text { A piece of } \\
\text { cigarette }\end{array}$ \\
\hline Average score & $\begin{array}{l}79.6 \\
3\end{array}$ & $\begin{array}{l}81.2 \\
5\end{array}$ & 5.625 & 7.625 & \\
\hline
\end{tabular}

\section{Customer's Opinion}

There are 16 works created on two occasions, all of which are refreshing, without similarity. Both production methods and creative types have their own characteristics. They are rare in China's public interest cigarette control videos. College students all have creative ideas and ideas, with their thinking also not limited by existing promotional materials.

However, regarding the purpose of tobacco control propaganda, the works of the students 2011 most did not achieve the desired effect of "Party A." In particular, the points that Party A hoped to convey failed to be expressed, without enough information points communicated, e.g. the animation of smoke dancing is novel in type and ha strong $\mathrm{s}$ visual impression, but "Party A" did not know what it wanted to express after reading it, and bluntly it lacks of the desire to advise smoking cessation, and additionally the data was not accurate.

The works of students 2013 are relatively more satisfied, which not only have a variety of ways of expression, but it can present the purpose of publicity. Most prominently, they 
communicated more knowledge of tobacco hazards, and have relatively accurate data. Because this is a landing project signed with Party A, it needs a monitoring by Party A in the entire process, the students made a long actual docking with Party A , and the final works basically achieved the Party A's expectation, which means it is more in line with market demand. It is the most important that the students really experienced the process of communicating with customers in this process, and this is a very important ability for the students in the future work. A direct connection with the society at the stage of college curriculum is the real growth of students, and it is also the purpose of applied education.

\section{Effect Analysis}

The students of 2011 and 2013 are not significantly different in the scores from their instructors, indicating that students have little difference in professional production techniques and all can understand the instructor's intentions. In other words, there are no obvious differences between the students of the two sessions before and after teaching of this animation creation course, and there is no difference in the ability of students to master professional skills.

(1) From the perspective of customer's satisfaction ratings, it is particularly important to communicate with customers prior to production. From the results of actual practice of the students of 2013, the professional training on the topic-related knowledge background and the communication with customers play a key role, so that they get better customer evaluation. And two of the works were eventually used in the official publicity by the Tobacco Hazards and Control Office of the Yunnan Provincial Institute of Health Education. While no works of the students 2011 is selected, and it is worth our reflection.

(2) From the award of the works, when we sent these 16 works together to participate in some animation competitions, the works of the students of 2011 won more awards, that is to say, when the students are out of the concept of "customer requirements", they have greater creation space and wider and more creative imagination, and their creative ideas are more valued by the relevant competition organizing committee.

\section{CONCLUSION}

For the student of design-based digital medias, no creativity is bruising, lack of creativity is like a chef has no sense of taste, but only the unrestrained and vigorous imagination in the creation is far not enough. They should first understand the market, understand the needs of customers; In other words, since the orientation of creation is to be a propaganda film, they must first consider the effect of publicity, and how we can attract people's eyeballs, and successfully convey the information to be promoted to the object of the publicity.

But if blindly catering to customer's needs, sometimes their thinking will be completely dragged by the customer's thinking and they will lose their own creative ideas. The final work may meet some of the requirements of the customers in some degree, and it will be marketized, but it will lose its creative factors of advertising.
From the previous conclusion, it can be know that the applied education in digital media in colleges needs the combination of theory and practice, and it should cultivate the students' ability in actual project, communication with customers, and in analysis and pressure resistance in actual project creation. At the same time, we must also pay attention to their creative thinking, and really combine their creativity and the needs of the clients. This model of education can enable the students to become advanced applied talents with practical abilities, innovative abilities, and entrepreneurial spirit, and also can solve the separation of the modern art education theory in colleges from the practice.

\section{REFERENCES}

[1] Li Wangxiu. Status Quo and Analysis of Undergraduate Education of Digital Media in China [J] Modern Educational Technology, 2012 (09). 李望秀.我国数字媒体专业本科教育现状与分析【J】现代教育技 术, 2012 (09)

[2] Hu Jie. Constructing the "Trinity" practice teaching mode of digital media education [J] Experimental Technology and Management, 2011 (03). 胡杰.构建数字媒体教育 “三位一体” 的实践教学模式【J】 实验技术与管理，2011（03）

[3] Li Jing. Thinking on Digital Media Education [J] Neijiang Technology, 2008 (02). 李晶. 对数字媒体专业教育的思考【【J内江科技, $2008(02)$ 